\title{
GYMNOSTOMA TASMANIANUM SP. NOV., A FOSSIL CASUARINACEAE FROM THE EARLY OLIGOCENE OF LITTLE RAPID RIVER, TASMANIA, AUSTRALIA
}

\author{
Greg Guerin ${ }^{1, *}$ and Robert S. Hill/2,* \\ *Centre for Evolutionary Biology and Biodiversity, Department of Environmental Biology, University of Adelaide, South Australia 5005, \\ Australia; +Centre for Evolutionary Biology and Biodiversity, South Australian Museum, North Terrace, Adelaide, South Australia \\ 5000, Australia; and ¥Department of Environmental Biology, University of Adelaide, South Australia 5005, Australia
}

\begin{abstract}
Macrofossils of Casuarinaceae from Early Oligocene sediments at Little Rapid River, Tasmania, are assigned to a new species, Gymnostoma tasmanianum. This is only the second species of fossil Gymnostoma to be formally described and the first species of Gymnostoma to be described from Tasmania. The species is known from both vegetative and reproductive organs. The new taxon is distinguished from other known species by its small stomata, short article length and tooth width, small length : width ratio of articles, glabrous articles, stomata in two to five rows, and teeth elongate with acute apices and sinuses. The fossil record shows that Gymnostoma once had a much wider distribution in Australia than its current occurrence in far north Queensland.
\end{abstract}

Keywords: Casuarinaceae, Gymnostoma, Tasmania, macrofossil, Cenozoic.

\section{Introduction}

The Casuarinaceae have a significant fossil record, particularly in the Australian Paleogene, but macrofossils are also known from South America and New Zealand, and pollen has been reported from South Africa (Christophel 1980; Coetzee and Praglowski 1984; Scriven and Christophel 1988; Hill 1994; Scriven and Hill 1995). Unfortunately, many of these fossils provide little useful information on the overall history of the family either because they are poorly preserved and difficult to study or because they have not been described in detail or undergone formal taxonomic treatment (Christophel 1980; Hill 1994; Scriven and Hill 1995). In the past, uncertainty in the taxonomy of extant species has also hampered and confused efforts to accurately place fossil species (Scriven and Hill 1995). Only one fossil species of Gymnostoma has been formally described, Gymnostoma antiquum L.J. Scriven $\&$ R.S. Hill from Late Paleocene sediments at Lake Bungarby, New South Wales. This is also the oldest known macrofossil record of the family (Scriven and Hill 1995).

The specimens recovered from the Early Oligocene Little Rapid River sediments in Tasmania provide an excellent opportunity to expand our understanding of the fossil record of the Casuarinaceae in space and time and, even more importantly, in morphological detail. The presence of vegetative and both male and female reproductive material with excellent preservation makes a full taxonomic investigation of this fossil taxon possible.

\footnotetext{
${ }^{1}$ E-mail greg.guerin@adelaide.edu.au.

22E-mail bob.hill@adelaide.edu.au.
}

Manuscript received August 2002; revised manuscript received February 2003.

\section{Material and Methods}

\section{Fossil Locality}

The Little Rapid River fossil-bearing sediments are exposed by a road cutting in the northwest of Tasmania, $35 \mathrm{~km}$ south of Smithton. The sediments are located in an old river valley at relatively low altitude $(90 \mathrm{~m}$ above sea level) and are dated palynologically as Early Oligocene (Macphail et al. 1994). The fossiliferous sediments consist of two main horizons of fine silt and sand (LRR1 and LRR2) separated by a thin band of lignite. The fossil plant assemblage represents a diverse rainforest community that grew in an environment of high, even rainfall and moderate temperatures. The sediments have yielded many angiosperm, fern, and conifer macrofossil taxa (Hill and Scriven 1997).

\section{Specimen Preparation and Examination}

The fossils were obtained from collections housed in the Department of Environmental Biology, University of Adelaide, that were originally collected by R. S. Hill from 1992 to 1998. Blocks of sediment were immersed in warm $10 \%$ ww aqueous hydrogen peroxide until the sediment disaggregated. The resultant slurry was then washed through a series of sieves from $500 \mu \mathrm{m}$ to $100 \mu \mathrm{m}$. The retained material was sorted under low magnification using a dissecting microscope. Specimens were stored in $70 \%$ ethanol. Vegetative branches (articles) and inflorescences were removed from ethanol and placed in hydrofluoric acid overnight to dissolve particles of sediment adhered to them. The fossils were then washed thoroughly and replaced in ethanol. The infructescences examined required no initial preparation.

Specimens were mounted on aluminium stubs with pipettes or brushes using double-sided adhesive tape. Once the specimens were dry, the stubs were coated with carbon and gold 
and viewed with either a Phillips XL20 scanning electron microscope (SEM) or a Phillips XL30 field SEM, both operated at $10 \mathrm{kV}$. In total, ca. 40 specimens were examined in detail.

Cuticle was removed from 16 articles by placing them in an aqueous solution of $5 \%$ chromium trioxide for ca. $1 \mathrm{~h}$ until the cuticles had cleared. The fragile and fragmented cuticles were pipetted into dishes, thoroughly washed, and then neutralized with a small amount of ammonia ( $10 \%$ solution) before being mounted on SEM stubs by collecting pieces on a fine brush and dipping them into a drop of water placed onto double-sided tape. Once dried, the stubs were coated and viewed as above.

The approach used in identifying the taxon follows that used by Scriven (1988) for Gymnostoma, which has been adapted and modified by current workers for morphological research on the entire Casuarinaceae family (R. S. Hill, K. Wilson, and D. Steane, unpublished data). This involves scoring quantitative characters. All measurements were replicated up to a maximum of 25 times. The anatomical terminology used follows that of Scriven and Hill (1995).

\section{Results}

The organically preserved and three-dimensional material belonging to the Casuarinaceae from the Little Rapid River sediments includes articles and male and female inflorescences and infructescences (fig. $1 A, 1 B, 1 D-1 F$; fig. $2 A-2 C$ ). The cuticle of the articles is also relatively well preserved and was successfully removed for examination, although the external side was often damaged and lacking in cell detail (figs. 1C, 2D).

Since specimens from the two horizons (LRR1 and LRR2) were indistinguishable, the data were combined, and the fossils are treated as a single species. The male inflorescences are attached to articles that are identical to sterile articles; hence, all these fossils belong to the same species. None of the infructescences known are attached to articles; however, given that the articles occur in abundance in the deposit (thousands of specimens) and are all the same species and that only a small number of morphologically uniform infructescences are known, it is very probable that all organs described belong to the same species.

The species is moderately variable in the length and width of articles $(0.86-2.27 \mathrm{~mm}, 0.39-0.75 \mathrm{~mm})$ and teeth (0.27-0.47 mm, 0.14-0.27 mm); other measured traits such as length and width of guard cells and length and width of stomatal complexes are less variable. In general, all qualitative characters were consistent. The number of cells between stomatal complexes was quite variable.

\section{Affinities with Extant Taxa}

The fossil taxon is clearly Gymnostoma because of the presence of the following characters: articles with four sides and four teeth (fig. $1 A, 1 B$ ), exposed stomata in shallow, open furrows (fig. 1C), male inflorescences with a compound arrangement of flowers subtended by two broad bracts (fig. $1 D$, $1 E$ ), female flowers forming a dense inflorescence (fig. $2 A$ ), and infructescences consisting of whorls of a few highly exserted bracteoles subtended by a single broad bract (fig. $2 B$,
2C). Pollen grains preserved in one specimen (fig. 1F) match the typical medium-sized triporate type found in all members of the family. The taxon is distinct from any extant species on the basis of vegetative morphology (R. S. Hill, K. Wilson, and D. Steane, unpublished data), although several species are superficially similar (table 1 ).

The fossil resembles the only extant Australian species, Gymnostoma australianum L.A.S. Johnson, in general appearance and because both are mainly glabrous with rather acute teeth (fig. 1A, 1B). However, G. australianum consistently has six rows of stomata, as compared with the fossil that has two to five but usually two to three (fig. 2D). Some features of Gymnostoma papuanum L.A.S. Johnson match those of the fossil, but many are incongruent, and the two are visually quite dissimilar. All anatomical features of this extant species are much larger than the fossil, and it has multicellular trichomes, while the fossil is glabrous. Gymnostoma sumatranum L.A.S. Johnson is also quite similar to the fossil but is easily separated from it by its conspicuous multicellular trichomes and tooth morphology. The fossil taxon has smaller dimensions for all of its parts than any living species, and no species matches more than a few of its multivariate characters. Given the extremely large number of fossil specimens recovered and their excellent state of preservation, it is unlikely that this small size is a result of taphonomy. The defining characters of the Little Rapid River fossils are the length and width of stomata, width of teeth, the length of the articles, and the length : width ratio of the articles (all smaller than any extant species). Other highly significant features include the shape of the tooth apices and sinuses. There is no single species that matches the infructescence of the fossil with regard to robustness, degree of bracteole exsertion, or size.

\section{Affinities with Previously Described Fossil Taxa}

Christophel (1980) stated that some records of fossil Casuarinaceae are so poorly preserved or identified that they can be discounted. However, there are numerous other reported fossils with far clearer affinities. To date, the only fossil formally described as Gymnostoma is Gymnostoma antiquum L.J. Scriven \& R.S. Hill from the Paleocene of Lake Bungarby, southeastern Australia (Scriven and Hill 1995; table 1). Although this species has some similarities with the Tasmanian fossil in being glabrous with acute teeth apices, it is distinct from the Little Rapid River species in that it has much larger article dimensions, rounded to obtuse tooth sinuses, only one to two stomatal rows in a band, and significantly larger infructescence dimensions.

However, a number of fossil taxa with clear affinities to Gymnostoma were previously named Casuarina before the monogeneric family was separated into four genera. For this reason, these taxa must be compared with the Little Rapid River species. Scriven and Hill (1995) discounted many of the reports of fossil Casuarinaceae in the literature, and only those that they considered to belong to the family are considered here. A Miocene species assigned to the Casuarinaceae by Campbell (1985) is not Gymnostoma (Scriven and Hill 1995). The species of Casuarinaceae reported from the Miocene Yallourn and Morwell coal seams by Pike (1953) and Blackburn (1985) does not match the Little Rapid River specimen, since 

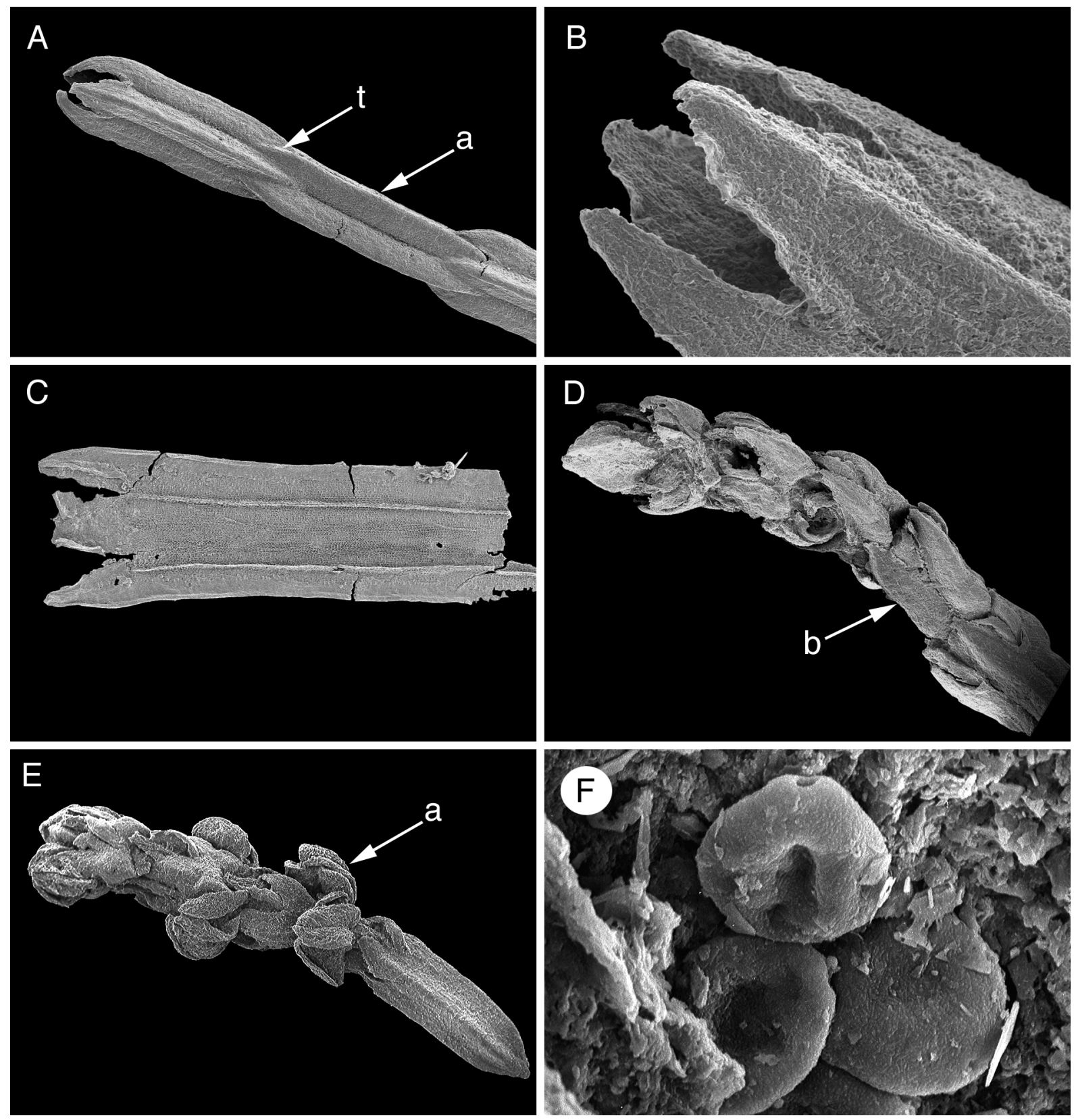

Fig. 1 Fossils of Gymnostoma tasmanianum sp. nov. from Little Rapid River (SEMs). A, Vegetative branchlet composed of articulated segments $(a=$ articles) surmounted by four teeth $(t)$ (specimen LRR2 334). $\times 25$. B. Detail of the four teeth at the top of an article (specimen LRR2 331). $\times 110 . C$, Complete cuticle from an article showing teeth with acute apices and sinuses and the slight furrows leading down from the sinus. The stomatal bands occur on either side of these furrows (specimen LRR2 034). $\times 30 . D$, Male inflorescence with paired bracts $(b)$ (specimen LRR1 1776). × 25. E, Holotype of G. tasmanianum (specimen LRR2 154). Male inflorescence with attached anthers $(a) . \times 17 . F$, Pollen grains within an anther on the holotype. $\times 1000$.

it has between five and eight rows of stomata compared with two to five (usually two to three) in the latter. Campbell and Holden (1984) described two species from the Late Oligocene to Early Miocene of New Zealand. Casuarina avenacea J.D. Campbell \& A.M. Holden (1984) has infructescences that are bigger than the Little Rapid River specimen and only moderate bracteole exsertion, while Casuarina stellata J.D. Campbell \& A.M. Holden is also bigger than the Little Rapid River species.
No cuticle is available for either species, and the reported information includes confused terminology and insufficient description of morphological features beyond the generic level. Casuarina cookii von Ettingshausen (1883) lacks reproductive material and accessible specimens, but the species was described as having cylindrical articles with short oval teeth (Scriven and Hill 1995). For this reason, it is distinct from the Little Rapid River species, which has elongated teeth with 

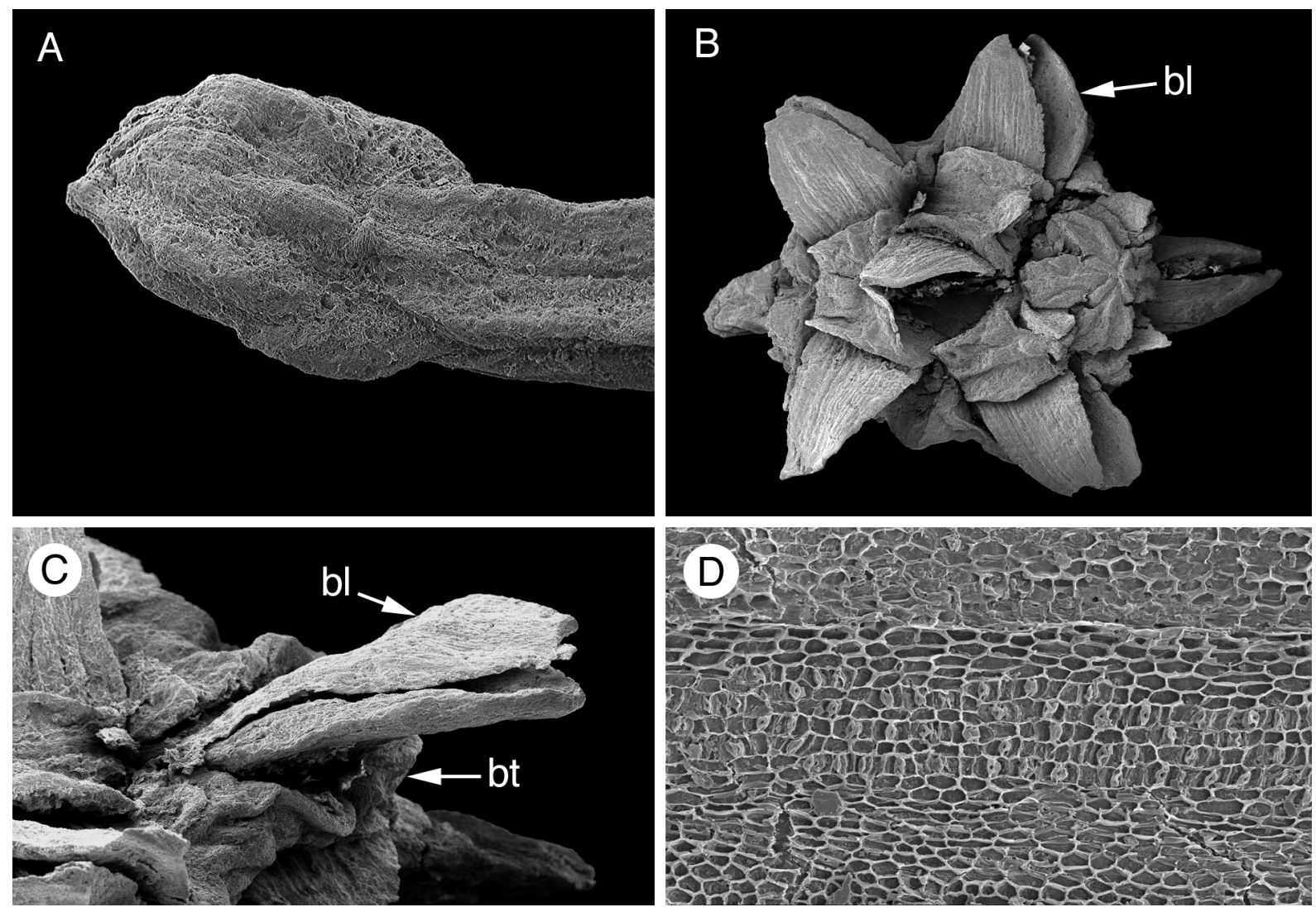

Fig. 2 Fossils of Gymnostoma tasmanianum from Little Rapid River (SEMs). A, Female inflorescence before bud break (specimen LRR1 287). $\times 32 . B$, Infructescence consisting of whorls of valves with highly exserted paired bracteoles $(b l)$ (specimen LRR1 4009). $\times 10 . C$, Closeup of the infructescence in $B$, showing paired bracteoles $(b l)$ forming a valve (compressed), subtended by a broad bract $(b t)$. $\times 25 . D$, Internal cuticle, showing a stomatal band varying between three and four stomata in width, running from left to right in the center. At the top are the cells in the furrow, which can be seen in fig. 1C (specimen LRR2 034). $\times 195$.

acute sinuses and apices. Finally, Casuarina patagonica Frenguelli (1943) is an impression fossil species, and there is a lack of detailed taxonomic information available with which to make specific comparisons (Christophel 1980).

In summary, the Little Rapid River fossils are distinct from all extant species and all formally described fossil species on the basis of morphology of either branchlets or infructescences. Some fossil taxa cannot be adequately compared because of lack of detail in their descriptions.

\section{Systematic Paleontology}

Order-Casuarinales

Family-Casuarinaceae R.Br.

Genus-Gymnostoma L.A.S. Johnson

Telopea, 2:83 (1980)

Species-Gymnostoma tasmanianum sp. nov. (Figs. 1, 2)

Holotype. LRR2 154 (fig. 1E, 1F).

Paratypes. LRR1 287 (fig. 2A), LRR1 1774-75, LRR1
1776 (fig. 1D), LRR1 4009 (fig. 2B, 2C), LRR1 4010-4011, LRR2 031-033, LRR2 034 (figs. 1C, 2D), LRR2 035-036, LRR2 037, LRR2 038-039, LRR2 331 (fig. 1B), LRR2 332-333, LRR2 334 (fig. 1A).

Diagnosis. Teeth acute at apices and sinuses and slightly obtuse in shape. Stomata in two to five (commonly two to three) rows within bands. Trichomes absent. Teeth small in length and width $(0.27-0.47 \mathrm{~mm}$ and $0.14-0.27 \mathrm{~mm}$, respectively), articles short in length $(0.86-2.27 \mathrm{~mm})$. Stomata small in length and width (guard cells 13.3-21.6 $\mu \mathrm{m}$ long $\times 6.4-9.3$ $\mu \mathrm{m}$ wide; guard cells and subsidiary cells $13.3-22.4 \mu \mathrm{m}$ long $\times$ 9.6-21.8 $\mu \mathrm{m}$ wide).

Type locality. Little Rapid River, Tasmania, Australia: $41^{\circ} 09^{\prime} \mathrm{S}, 145^{\circ} 14^{\prime} \mathrm{E}$, altitude $90 \mathrm{~m}$ a.s.l.

Etymology. From the Latin, "from Tasmania."

Repository. The holotype is stored in the Department of Environmental Biology, University of Adelaide.

\section{Species Description}

Articles of branchlets tetrahedral in cross section, 0.86-2.27 $\mathrm{mm}$ long, 0.39-0.75 mm wide. Teeth four per whorl, slightly obtuse to straight with acute sinuses and apices, 0.27-0.47 $\mathrm{mm}$ long, $0.14-0.27 \mathrm{~mm}$ wide. Stomata located in bands of 
Table 1

Features of Fossil and Selected Living Gymnostoma Species That Distinguish Them from G. tasmanianum

\begin{tabular}{|c|c|}
\hline Species & Distinguishing features \\
\hline \multicolumn{2}{|l|}{ Fossil: } \\
\hline G. antiquum & $\begin{array}{l}\text { Large articles, one to two stomatal } \\
\text { rows, large fruit size, rounded tooth } \\
\text { sinuses }\end{array}$ \\
\hline G. tasmanianum & $\begin{array}{l}\text { Small stomata, short article length and } \\
\text { tooth width, small length : width ratio of } \\
\text { articles, glabrous articles, stomata in two } \\
\text { to five rows, and teeth elongate with } \\
\text { acute apices and sinuses }\end{array}$ \\
\hline \multicolumn{2}{|r|}{${ }^{1}$} \\
\hline G. australianum & Consistently six rows of stomata \\
\hline G. papuanum & $\begin{array}{l}\text { Multicellular trichomes, larger dimensions } \\
\text { of vegetative organs }\end{array}$ \\
\hline G. sumatranum & $\begin{array}{l}\text { Multicellular trichomes, different tooth } \\
\text { shape }\end{array}$ \\
\hline
\end{tabular}

two to five rows, commonly two to three, along shallow furrows of articles, commonly with zero to one epidermal cell between rows and zero to one (but up to three) epidermal cell between individual stomata. Stomatal complexes 13.3-22.4 $\mu \mathrm{m}$ long $\times 9.6-21.8 \mu \mathrm{m}$ wide. Florin rings indistinct. Epidermal cells rectangular to hexagonal to chaotic, with smooth anticlinal walls and no structure visible on the internal cuticle, 9.1-26.7 $\mu \mathrm{m}$ in length $\times 2.4-13.3 \mu \mathrm{m}$ in width. Trichomes absent. Male inflorescences with a compound arrangement of flowers, each consisting of a pair of bracts subtending the deciduous tepal (absent) and single anther. Anthers with fully preserved pollen grains are visible on one specimen. Pollen grains match the type found in the family and are oblate, triporate, and scabrate with scabrae irregularly distributed across the grain. Female inflorescence known from a single specimen, typical of genus, a dense head of flowers. Infructescence valves four per whorl, with bracteoles highly exserted from body of infructescence at an angle of $90^{\circ}$. A broad bract subtends each pair of bracteoles (valve). Infructescence ca. 7 $\mathrm{mm}$ at widest point. No trichomes are visible on the bracteoles.

\section{Discussion}

The Little Rapid River species fits well into the genus Gymnostoma, since the male and female reproductive organs and articles are typical of the genus and the pollen morphology is typical of the family. However, it is distinct from any other described extant or fossil species in the following features: small stomata, short article length and tooth width, small length : width ratio of articles, glabrous articles, stomata in two to five rows, and teeth elongate with acute apices and sinuses. This highlights the point that as a genus, Gymnostoma has changed little since its appearance in the fossil record in the Paleocene, although a range of different species are known.
This may be a consequence of it remaining a rainforest dweller rather than radiating out into drier habitats. It cannot yet be said whether Gymnostoma is ancestral to the subfamily Cryptostomae, which has radiated into drier habitats, or a sister taxon. However, no intermediate forms are known. Molecular phylogenies have demonstrated the monophyly of the four extant genera in the Casuarinaceae and that Gymnostoma is sister to the other three genera (Sogo et al. 2001; Steane et al. 2003).

Gymnostoma tasmanianum is particularly well preserved, and there are many specimens of vegetative material and male and female inflorescences. This has allowed the species to be compared very closely with extant species.

The likely prevailing environment at the time of deposition at the Little Rapid River site has been clearly demonstrated through the diverse range of other species present in the fossil record (Hill and Scriven 1997). The interpretation of this Early Oligocene vegetation as closed rainforest is supported by the presence of Gymnostoma, which has unprotected stomata in a clearly mesic-adapted anatomy. Within forests today, Gymnostoma occurs in disturbed sites or along waterways (Barlow 1983; Wilson and Johnson 1989).

We also know that the genus was once present in Tasmania, far away from its current closest occurrence in the far north of Queensland (Gymnostoma australianum), a contraction in range presumably induced by climate change. All extant species occur in the tropics; hence, the overall drop in temperatures at more southern latitudes over the Tertiary may have caused the genus to become extinct in areas such as Tasmania.

Few fossil species assigned to the family have been formally described. In order for the intrafamilial relations to be better explored it would be useful for more specific identification and descriptions of fossils to be made, especially in light of the extensive taxonomic work being undertaken on extant species (R. S. Hill, K. Wilson, and D. Steane, unpublished data). It may then be possible to speculate on the evolutionary origin of the extant species.

To date, no individual fossil species of Gymnostoma has been identified from more than one location, and this has hampered efforts to reconstruct the history of the family during the Cenozoic and to link fossil records. It is yet to be determined whether this is because Gymnostoma has been a highly diverse genus for most of its history or because species known from the fossil record were transient. This makes it even more important that all known fossil records be examined in detail, especially given that it is now possible to accurately compare fossil taxa with extant species.

\section{Acknowledgments}

We thank Jo Shrapnel, Yvonne Menadue, David Christophel, Leonie Scriven, and John Conran. The Australian Research Council provided funding to support this research.

\section{Literature Cited}

Barlow BA 1983 Casuarinas: a taxonomic and biogeographic review. Pages 10-37 in SJ Midley, JW Turnbull, RD Johnson, eds. Casuarina ecology, management and utilization. CSIRO, Melbourne. Blackburn DT 1985 Palaeobotany of the Yallourn and Morwell coal 
seams. Palaeobotanical Project, report 3. State Electricity Commission of Victoria.

Campbell JD 1985 Casuarinaceae, Fagaceae, and other plant macrofossils from Kaikorai leaf beds (Miocene) Kaikorai Valley, Dunedin, New Zealand. N Z J Bot 23:311-320.

Campbell JD, AM Holden 1984 Miocene Casuaracean fossils from Southland and Central Otago, New Zealand. N Z J Bot 22:159-167.

Christophel DC 1980 Occurrences of Casuarina megafossils in the Tertiary of south-eastern Australia. Aust J Bot 28:249-259.

Coetzee JA, J Praglowski 1984 Pollen evidence for the occurrence of Casuarina and Myrica in the Tertiary of South Africa. Grana 23: 23-41.

Frenguelli J 1943 Restos de Casuarina en el Mioceno de el Mirador Patagonia Central. Notas del Museo de La Plata 8:349-354.

Hill RS 1994 The history of selected Australian taxa. Pages 390-420 in RS Hill, ed. History of the Australian vegetation: Cretaceous to Recent. Cambridge University Press, Cambridge.

Hill RS, LJ Scriven 1997 Palaeoclimate across an altitudinal gradient in the Oligo-Miocene of northern Tasmania: an investigation of nearest living relative analysis. Aust J Bot 45:493-505.

Macphail MK, NF Alley, EM Truswell, IRK Sluiter 1994 Early Tertiary vegetation: evidence from spores and pollen. Pages 189-261 in RS Hill, ed. History of the Australian vegetation: Cretaceous to Recent. Cambridge University Press, Cambridge.
Pike KM 1953 Fossil fruiting cones of Casuarina and Banksia from Tertiary deposits in Victoria. Proc R Soc Vic 65:1-9.

Scriven LJ 1988 A morphological comparison of Tertiary megafossil and extant species of Gymnostoma L. A. S. Johnson (Casuarinaceae). Honors thesis. University of Adelaide.

Scriven LJ, DC Christophel 1988 A numerical study of extant and fossil Gymnostoma. Pages 137-147 in JG Douglas, DC Christophel, eds. Proceedings of the Third International Organisation of Palaeobotanists Conference. A-Z, Melbourne.

Scriven LJ, RS Hill 1995 Macrofossil Casuarinaceae: their identification and the oldest macrofossil record, Gymnostoma antiquum sp. nov., from the Late Paleocene of New South Wales, Australia. Aust Syst Bot 8:1035-1053.

Sogo A, H Setoguchi, J Noguchi, T Jaffré, H Tobe 2001 Molecular phylogeny of Casuarinaceae based on $r b c L$ and $m a t K$ gene sequences. J Plant Res 114:459-464.

Steane DA, KL Wilson, RS Hill 2003 Using matK sequence data to unravel the phylogeny of Casuarinaceae. Mol Phylogenet Evol 28: $47-59$.

von Ettingshausen C 1883 A contribution to the Tertiary flora of Australia. Geol Mag 10:153-157.

Wilson KL, LAS Johnson 1989 Casuarinaceae. Pages 100-135 in AS George, ed. Flora of Australia. Vol 3. Hamamelidales to Casuarinales. Australian Government Publishing Service, Canberra. 